\title{
EEUWENOUDE VIETNAMESE KALKPOTJES IN NEDERLANDSE MUSEA
}

Vietnam en Nederland liggen ver van elkaar, maar toch hebben ze een historische betrekking met elkaar. In de Gouden Eeuw onderhielden de Republiek der Zeven Verenigde Nederlanden en de Verenigde Oost-Indische Compagnie (VOC) banden met zowel Dang Trong (het zuiden van Vietnam) als Dang Ngoai (het noorden). ${ }^{1}$

Sinds 1620 woedde er in Vietnam een burgeroorlog en pas rond 1786 werd het land herenigd. In de tussentijd had de VOC met de twee verschillende rijken te maken. De handelsplaats in Zuid-Vietnam was Hoi An (er bestaat nog steeds een plaatsje met deze naam in de provincie Quang Nam in Centraal-Vietnam). In Noord-Vietnam had de VOC een factorij in de havenplaats Pho Hien (tegenwoordig is daar een dorpje met dezelfde naam in de omgeving van de stad Hung Yen aan de Rode Rivier), de belangrijkste plaats na de hoofdstad Ke Cho (tegenwoordig Hanoi), waar handel met het buitenland werd gedreven. De VOC was daar tot het midden van de $18^{\mathrm{e}}$ eeuw gevestigd en de meest verhandelde goederen waren zijde, kruiden, keramiek, rietsuiker, bamboe en houten meubelen.

De VOC heeft daar toen een soort erwt ingevoerd die door de Vietnamezen dau Hoa Lan wordt genoemd. Dat betekent letterlijk: 'Nederlands erwtje'. Dit is het in Nederland bekende doperwtje of tuinerwtje (Engels: field pea, Frans: petit pois, Linnaeus: Pisum sativum). In Vietnam zijn tegenwoordig meer dan 200 verschillende soorten erwten en bonen bekend, maar - gek genoeg - heeft geen enkele een naam die hierop lijkt. ${ }^{2}$

Vanuit de factorij in Noord-Vietnam heeft de VOC via Batavia, het hoofdkantoor van het handelsconcern in Azië, ook veel kleine stukken keramiek naar Nederland gebracht. Of daaronder ook kalkpotjes waren, weet helaas niemand.

Die Vietnamese kalkpotjes zijn het onderwerp van deze bijdrage. Ze dienen voor het bewaren van gebluste kalk, dat een van de drie essentiële componenten is van een betelpruim. De andere twee componenten zijn de areca-noot (de noot van Areca catechu L.) en het blad van de betelplant (het blaadje van Piper betel L.). Het gebruik om betelpruim te kauwen is in Vietnam al bekend vanaf het eerste millennium voor Christus. Deze gewoonte bloeide vooral in de $16^{\mathrm{e}}$ tot $19^{\mathrm{e}}$ eeuw. In die tijd praktiseerde ongeveer $95 \%$ van de bevolking (vanaf het $12^{\mathfrak{c}}$ of $13^{\mathrm{e}}$ jaar tot het eind van het leven) dagelijks het betelkauwen. In de $17^{\mathrm{e}}$ eeuw waren er in Ke Cho zo'n 50.000 betelverkopers. ${ }^{3}$ Tegenwoordig doen alleen nog vrouwen van boven de 50 die op het platteland in Centraal-Vietnam leven, aan dit gebruik. Het betelkauwen in Vietnam is meer dan het gebruiken van een genotmiddel alleen; er is een godsdienstige kant met veel kleurrijke rituelen aan verbonden. ${ }^{4}$ 

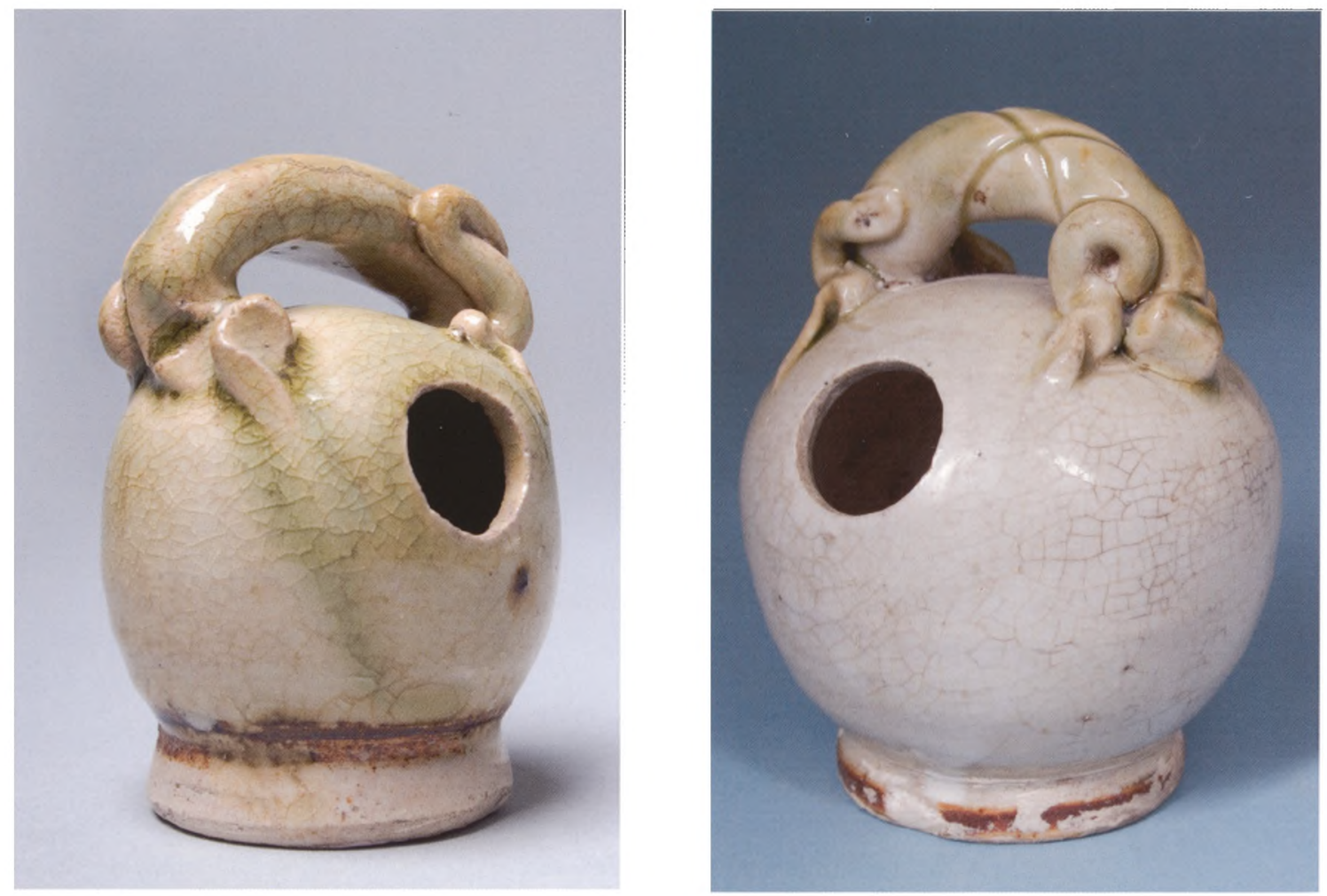

Afbeelding 1 (links) Het eerste geregistreerde kalkpotje in Nederland, steengoed, hoogte $8,5 \mathrm{~cm}$., diameter $5 \mathrm{~cm}$., Vietnam, $14^{\circ}$ eeuw, Museum Princessehof, Leeuwarden, inv.nr 2066

\section{Afbeelding 2}

Het oudste Vietnamese kalkpotje in Nederland, steengoed, hoogte 10,7 cm., diameter $7,8 \mathrm{~cm}$., Vietnam, $14^{\circ}$ eeuw, Museum Princessehof, Leeuwarden, inv.nr OKS $1957 / 25$
Zoals ook in andere landen in Zuid- en Zuidoost-Azië waar betel gekauwd wordt, bestaan in Vietnam eigen benodigdheden voor het betelkauwen. ${ }^{5}$ Het zijn acht onderdelen, waarvan de kalkhouder er één is. De Vietnamese kalkhouders kunnen in drie typen worden verdeeld: 1) een metalen buisje, 2) een potje van steengoed, porselein of metaal, en 3) een grotere pot van steengoed. De kalkpotten in dit artikel zijn allemaal van het tweede type. Een Vietnamees kalkpotje - meestal van steengoed - bestaat in het algemeen uit een ronde pot op een voet, met een hengsel. Bovenop de pot en onder het hengsel is soms een bultje aangebracht, de tepel, en aan de voorkant van de buik bevindt zich een eenvoudig gat, de opening waardoor de kalk eruit gelepeld kan worden. ${ }^{6}$

Tussen 1967 en 1972 hebben Franse conservatoren, onder wie Solange Thierry, verbonden aan het Musée de l'Homme in Parijs, onderzoeksreizen gemaakt langs de belangrijkste musea van Nederland, in Amsterdam, Leiden, Rotterdam, Groningen en Breda, op zoek naar objecten die verband houden met het betelkauwen. Zij hebben toen geen enkele kalkpot aangetroffen. ${ }^{7}$ In 2006 en 2007 heeft ondergetekende het nog een keer geprobeerd. Met de verschillende Nederlandse musea is contact opgenomen en de collecties zijn onderzocht. Het resultaat is de vondst van zes Vietnamese kalkpotjes: twee in het Keramiekmuseum Princessehof in Leeuwarden, drie in॰Museum 3 12: 02:58PM Volkenkunde in Leiden, en één in het Tropenmuseum in Amsterdam.ia free access 


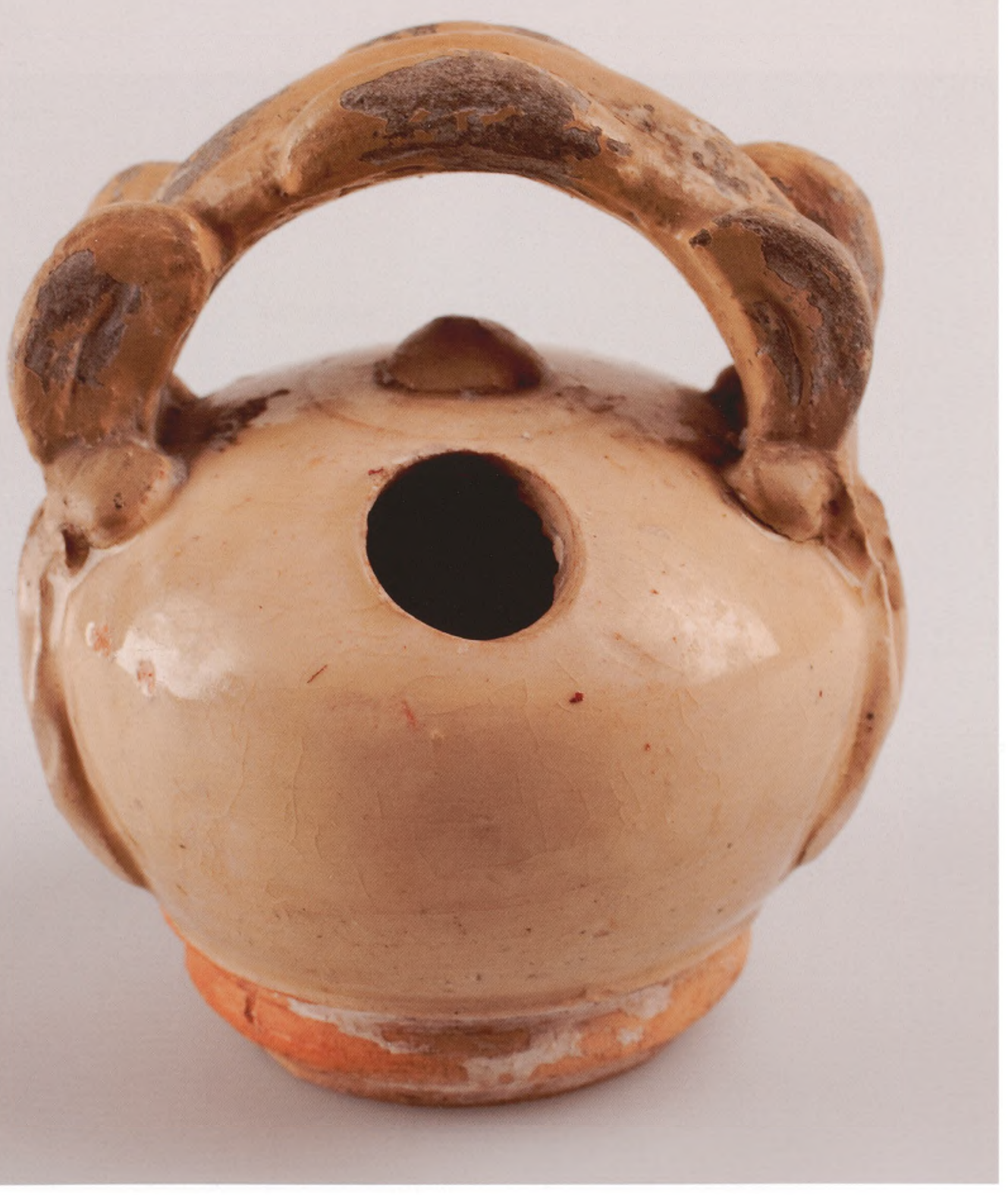

Afbeelding 3 (boven)

Globevormig potje met

lichtgeel glazuur,

steengoed, hoogte 13

cm., diameter 9,8 cm.,

Vietnam, $18^{e}$ eeuw,

Museum Volkenkunde,

Leiden, inv.nr 2917-44

(volgende pagina's)

Afbeelding $4^{a}$

Voorzijde van een

bijzonder kalkpotje,

beschilderd met een

gedicht, porselein,

hoogte $13,8 \mathrm{~cm}$.,

diameter 10,7 cm.,

Museum Volkenkunde,

Leiden, inv.nr 5442-1
Afbeelding $\mathbf{4 b}^{\mathrm{b}}$

Achterzijde van het potje van afb. $4^{a}$ 


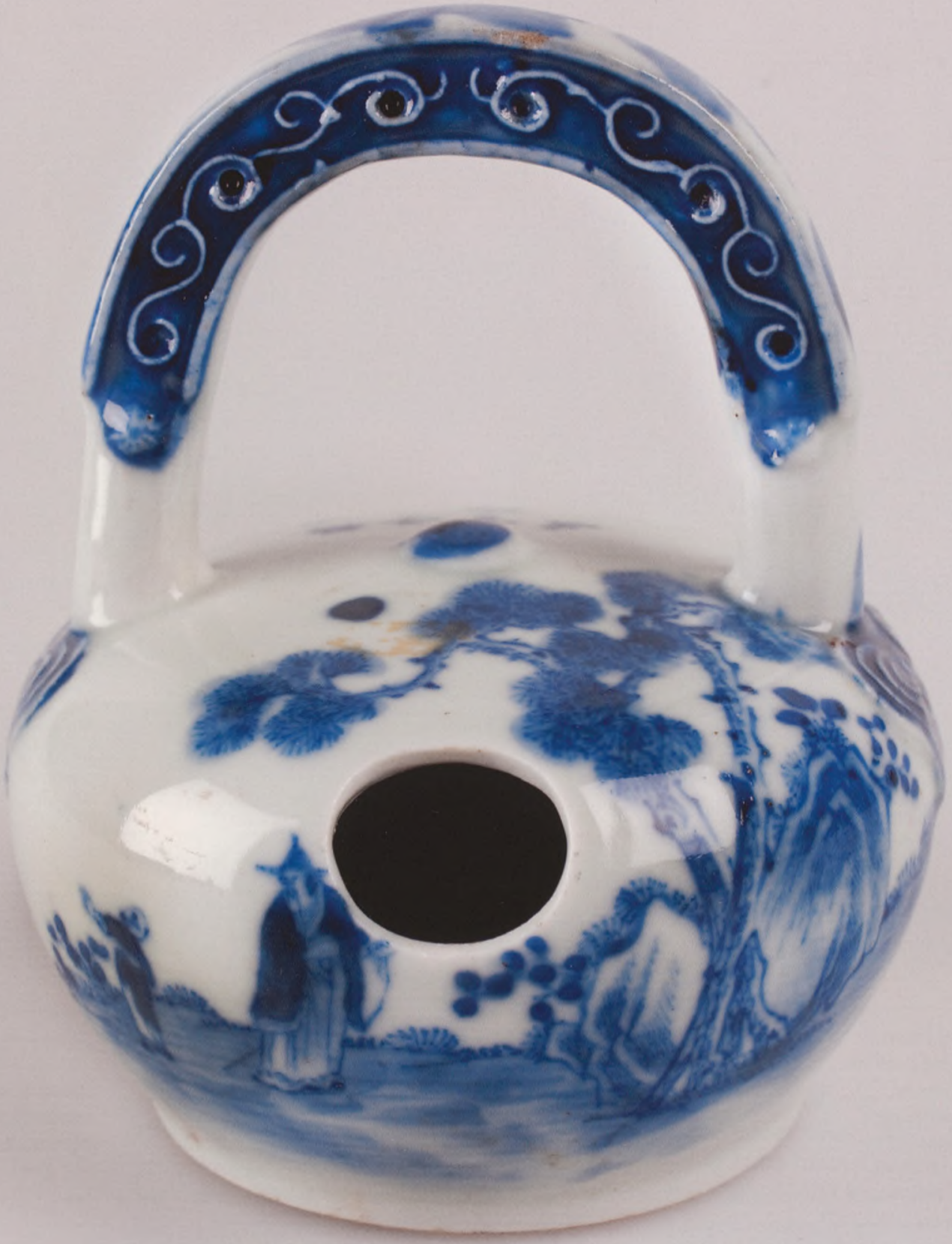




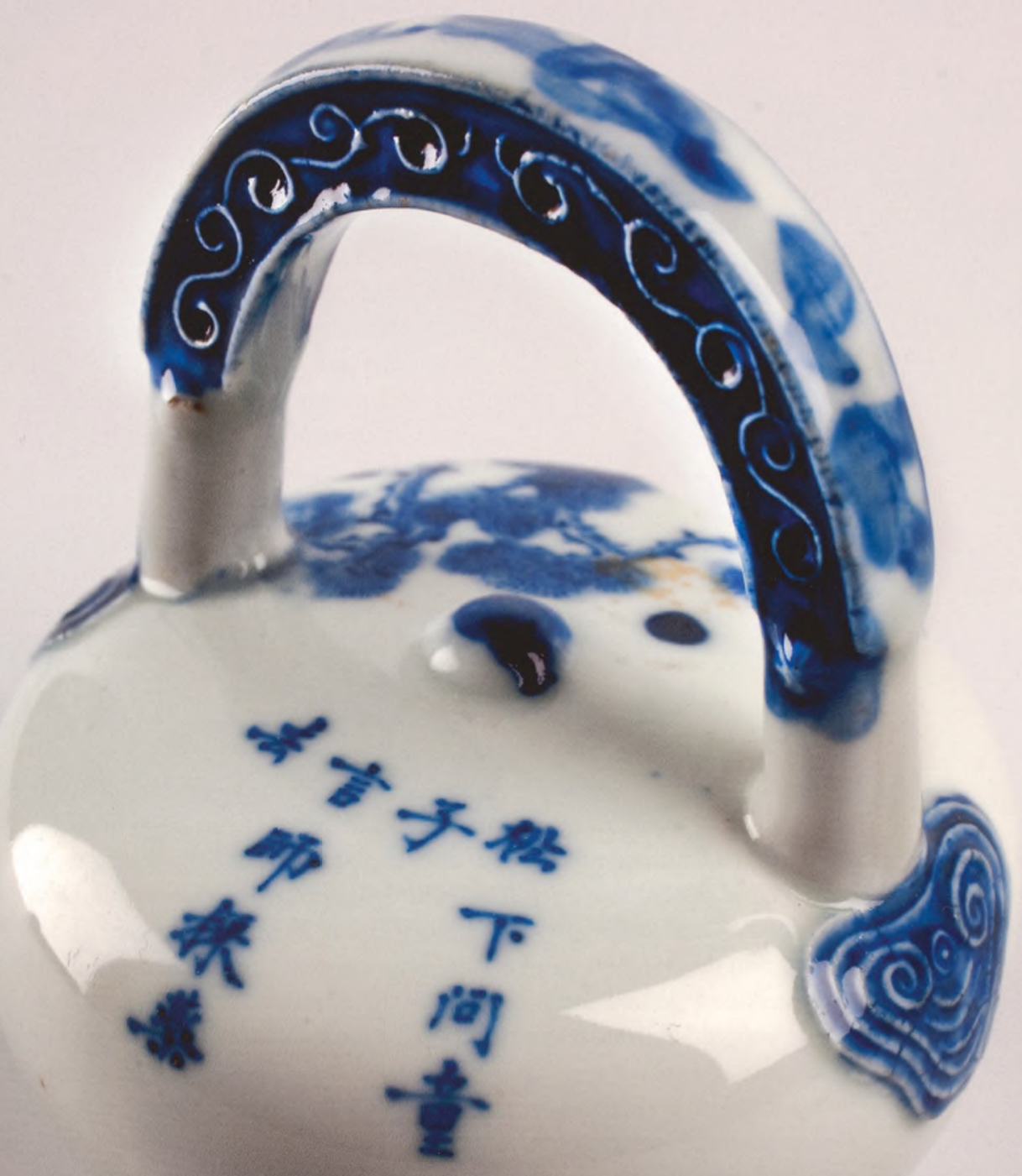


Het lijkt erop dat deze musea de kalkpotjes bij toeval hebben verworven tussen 1949 en 2006. In 1949 verwierf Museum Princessehof het eerste potje (afb. 1) en in 2006 schonk een Vietnamese inwoner van Den Haag Museum Volkenkunde in Leiden het laatste potje (afb. 5). Er is dus geen enkele relatie met de handelsbetrekkingen in de Gouden Eeuw.

\section{Hieronder volgt een beschrijving van deze zes potjes.}

Het eerste potje is in Museum Princessehof in Leeuwarden en werd 21 november 1949 aangekocht (afb. 1). Het is rond en heeft de typische vorm van een areca-noot. De opening is rond en hoog geplaatst. Het hengsel is gebogen en heeft de vorm van een gestileerd dier. De voet is recht met chocoladekleurige ring, de bodem is hol. Het is van lichtgrijs geglazuurd steengoed zonder decoratie.

Het tweede potje is ook in Museum Princessehof in Leeuwarden en werd in februari 1957 verworven (afb. 2). Het potje heeft ook een areca-noot vorm. De opening is rond en hoog geplaatst. Het hengsel loopt horizontaal en heeft de vorm van een areca-baard (een groeisel aan de areca-noot). De voet is recht met chocoladekleurige ring, de bodem is hol. Het is van steengoed met lichtgrijze, gecraqueleerde, groenige glazuur zonder decoratie. Dit is het oudste Vietnamese kalkpotje in Nederland.

Het derde potje is in Museum Volkenkunde in Leiden (afb. 3) en werd verworven in 1951. Het potje is bol. De opening is rond en hoog geplaatst. Erboven zit de tepel. Het hengsel is gebogen en heeft de vorm van een arecabaard. De voet is driehoekig en heeft een donkergele kleur, de bodem is hol. Het is van lichtgeel geglazuurd steengoed zonder decoratie.

Het vierde potje is ook in de Leidse verzameling en werd in 1986 verworven ( $a f b .4 a$ en b). Het is heel bijzonder. Het heeft de vorm van een pompoen. De opening is ovaal en laag geplaatst. Het hengsel is een hoge boog die is versierd met krullende lijnen. De tepel is plat. De voet is heel laag en de bodem glad. Het is van porselein met bijzondere, onderglazuurblauwe decoratie op een melkwitte ondergrond. Het is artistiek gedecoreerd op beide zijden; aan de ene kant een voorstelling, aan de andere kant een tekst. De tekst verklaart de voorstelling, en beide zijn ontleend aan de Chinese kunst. Op de voorzijde is een scène uitgebeeld: links wijst een jongetje naar achteren als antwoord op de vraag van de staande man in de kleding van een stedeling in het midden, en rechts van de opening staan een paar dennenbomen. Op de achterzijde zijn tien karakters gekalligrafeerd, in vier rijen, van boven naar beneden en van rechts naar links: (1) tung ha van dong, (2) tu, (3) ngon su thai duoc, (4) khu. Dat is: 'In het den[nenbos] stelt [de bezoeker] een vraag aan de jongen [die] antwoordt, dat de meester is uitgegaan om geneeskrachtige planten te plukken.'

Alle tien karakters zijn geschreven in khai thu, de standaard schrijfstijl, waarvan negen karakters in phon the, de traditionele schrijfstijl, en alléén het derde karakter van de eerste regel in gian the, de vereenvoudigde vorm. Opgemerkt dient nog te worden, dat het vierde karakter van de eerste regel betekent 'een jongen', en niet 'een jonge dienaar', zoals vaak is vertaald. 


\section{Afbeelding 6}

Kalkpotje met da Iuonglazuur, steengoed, hoogte $16,5 \mathrm{~cm}$., diameter $14,5 \mathrm{~cm}$., Vietnam, eind $19^{\circ}$, begin $20^{\circ}$ eeuw, Tropenmuseum, Amsterdam, inv.nr 5703-18
Het vijfde kalkpotje, dat zich bevindt in Museum Volkenkunde in Leiden, verworven in 2006, is ook uitzonderlijk omdat alle benodigdheden voor het functioneren van een kalkpotje er nog bij zijn ( $\mathrm{afb}$. 5). Geen museum, zelfs niet in Vietnam, heeft in zijn collectie een kalkpotje met de bijbehorende bronzen spatel (lengte $20,8 \mathrm{~cm}$.), het metalen deksel (deksel $8,9 \mathrm{~cm}$.) en het steengoed schoteltje (hoogte $2,4 \mathrm{~cm}$., diameter $12,6 \mathrm{~cm}$.). Het potje en het schoteltje zijn, denken we, van dezelfde datum, de spatel is wat later en het deksel is er recent, om en nabij de jaren '50 van de vorige eeuw, bijgemaakt. Dit potje is eerst aan het eind van de $19^{e}$ of het begin van de $20^{e}$ eeuw in Hanoi in Noord-Vietnam gebruikt, daarna,nin 1954 , naar Saigon in Zuid- ${ }_{-2}$ : 02 : $58 \mathrm{PM}$ Vietnam gebracht. In 1975 is het met een nakomeling van de oorsprónkelijkè $e^{c c e s s}$ 
eigenaresse naar Californië in de Verenigde Staten gekomen toen deze vluchtte, in 2004 mee naar Den Haag verhuisd, om ten slotte in 2006 in het Rijksmuseum voor Volkenkunde in Leiden te belanden. Het potje heeft de vorm van een pompoen. De opening is rond en hoog geplaatst. Het hengsel is licht gebogen en is beschilderd met gestileerde bladeren. De tepel is laag. De voet is hol. De pot staat op een schoteltje. Het potje is van lichtgeel geglazuurd steengoed versierd met lichtblauwe penseelstreken op de voor- en achterkant. Over het lichaam heeft zich door jarenlang gebruik een korst van gedroogd kalksmeersel gevormd.

Het zesde potje in Nederland werd in 1997 verworven door het Tropenmuseum in Amsterdam (afb. 6). Het is een bolvormig potje. De opening is klein, rond en hoog geplaatst. Het hengsel is plat en versierd met een arecabloem. Vermoedelijk bevindt zich een tepel onder de dikke, witte gedroogde kalklaag. De voet is glad, laag en lichtbruin geglazuurd. Het is een steengoed potje met bruin da luon (palingvel)-glazuur. Dit glazuur is specifiek voor pottenbakkerijen in Phu Lang (Bac Ninh provincie) en Bat Trang (omgeving van het huidige Hanoi). Het vertoont eveneens sporen van jarenlang gebruik.

Gebaseerd op de vergelijking van onder andere de vorm en grootte van het hengsel, de vorm, glazuur en decoratie van het potje, de vorm en het glazuur van de voet, de kleur en kwaliteit van het glazuur, stellen we de volgende productiedata voor: eind $14^{\mathrm{e}}$ eeuw voor de twee potjes in Leeuwarden (afb. 1 en 2 ), $18^{\mathrm{e}}$ eeuw voor het bolvormige potje in Leiden ( $\mathrm{afb}$. 3), begin $19^{\mathrm{e}}$ eeuw voor het bleu-de-Hue potje (afb. 4) en eind $19^{\mathrm{e}}$ of begin $20^{\mathrm{e}}$ eeuw voor de twee laatste potjes (afb. 5 en 6).

In Nederlandse musea zijn dus waarschijnlijk slechts deze zes Vietnamese kalkpotjes te vinden. Hoewel dit maar een klein aantal is, laten ze tezamen het hele ontwikkelingsproces van deze bescheiden keramiekvorm zien. Maar het is goed mogelijk dat er in Nederland in particulier bezit meer Vietnamese kalkpotjes zijn. Ondergetekende hoopt dat onder de lezers van deze bijdrage mensen zijn die andere kalkpotjes weten te vinden. De auteur stelt alle inlichtingen hierover op prijs. Hij is te bereiken via nguyenxhien@gmail.com.

\section{Noten}

* Met dank aan Pauline Lunsingh Scheurleer voor het redigeren van dit artikel.

1. Nguyen Xuan Hien, 'Historische relaties tussen Vietnam en Holland - Enkele chronologische fragmenten uit de zeventiende eeuw', Viet Nam nguyet san 71 (januari - februari 1991), pp. 41-44.

2. Nguyen Xuan Hien, Op.cit. (noot 1), p. 42.

3. A. de Rhodes, Histoire du royaume du Tonkin, 1651. Introduction et notes par J.-P. Duteil, Parijs, 1999, p. 38.

4. Zie Nguyen Xuan Hien, Betel-chewing Customs in Vietnam - from Practice to Ritual, Chicago etc., 2009.

5. Zie Nguyen Xuan Hien en P.A. Reichart, 'Betel-chewing in Mainland Southeast Asia', International Institute for Asian Studies Newsletter 47 (2008), pp. 26-27.

6. Voor een overzicht van Vietnamese kalkpotten, zie Nguyen Xuan Hien, Vietnamese Lime-pots in their Evolutionary Perspective, Chicago etc., 2009.

7. S. Thierry, Le bétel - I. Inde et Asie du Sud-Est. Supplément d'Objets et Mondes, 1969, vol. IX, nr. 3, en S. Thierry, 'Sur l'usage du bétel: notes complémentairess' Objets et Mondes, 1975, vol. XV, nr. 1, pp. 77-92. 